\title{
A Study on Students' Attitude Towards Learning of English
}

\author{
L. Vidhya ${ }^{1}$, K. Anbazhagan², P. Vijayalakshmi Anbu ${ }^{3}$, Maanvi Suresh ${ }^{3}$ and Luqmaan Sharif ${ }^{3}$ \\ ${ }^{1}$ Department of English and Foreign Languages, SRMIST, KTR \\ ${ }^{2}$ Department of English and Foreign Languages, SRMIST, KTR \\ ${ }^{3}$ Department of Applied Psychology, Faculty of Allied Health Sciences, SRIHER (DU)
}

\section{ABSTRACT}

English, the language has gained its significance as an international language and is being used in all parts of the world. As reported by Graddol (1997), there are three types of English language speakers: 1. those who speak and have it as first language, 2.those who speak it as second or additional language, 3. those who learn it as a foreign language. There are many research findings to show that there are many affective variables that play a major role in affecting language learning. The present study aims to study the affective variable attitude and its role in learning English as a second language. The study focuses the tertiary level learners of a private medical institution pursuing their under graduation. The study participants were informed the purpose of conducting the study and they were assessed using (circulating) a questionnaire through Google-form targeting to extract their cognitive, behavioural and emotional attitude towards learning of English as second language. The data analysed reported that there is no significant difference in gender towards learning of English as a second language. But, there exists a difference with regard to their residential background.

\section{KEY WORDS: ATTITUDE, ENGLISH LANGUAGE LEARNING, AFFECTIVE VARIABLES, COGNITIVE, BEHAVIOURAL AND EMOTIONAL.}

\section{INTRODUCTION}

Learning a second language is a tiresome and reckless for many of its in takers.' In most countries English is considered as second, foreign or the business language. A non-native speaker at the tertiary level learns English as a second language and they in spite of being exposed to the learning of the language still finds it difficult to imbibe in to their learning process in order to express themselves well. What could be the reason for them to fail expressing themselves? In connection to this there is identification that certain affective filter that plays a major role in affecting the learning process. Krashen reports that the mental block such as lack of motivation and attitude affects the learning process.

To support Krashen's report many studies have shown that the affective blocks in learning is one of the reasons for poor performance in English language learning. Attitude according to many researchers is considered to be one of

Biosc Biotech Res Comm P-ISSN: 0974-6455 E-ISSN: 2321-4007

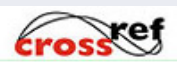

Identifiers and Pagination

Year: 2021 Vol: 14 No (8) Special Issue

Pages: 20-23

This is an open access article under Creative

Commons License Attribn 4.0 Intl (CC-BY).

DOI: $h t t p: / / d x$.doi.org/10.21786/bbrc/14.8.5 the main factors that affect the learning. There is a belief that exists, if a learner does not possess positive attitude towards language learning it is quite difficult to attain the best through learning of it. English at tertiary level has to be looked at as a language which would help them in preparing themselves to face competitive exams where it is given the utmost preference. This realization and need stands as the background of the study in concentrating on the three dimensions of attitude cognitive, behavioural and the emotional in carrying out the study among the tertiary level students of a reputed medical and research institute.

\section{Review Of Related Studies}

Definition and reviews: The Longman dictionary of Applied Linguistics and Language Teaching defines "attitude is what the speakers of different languages or language varieties have towards each other's languages or their own" (2002, p. 297). In the Indian context it is found that students need motivation to study language, specifically the professional students who have to get employment in field related to them need good communication and language skills which is possible only it they have positive attitude towards learning a language. One has to keep in mind that learning brings positivity in the individual's in terms of emotional and cognitive aspects that forms a basis on their behaviour. 
Learning a language is a boon and knowing a language would help an individual to express better. There are many reasons to set focus on students' attitude towards learning a language. Firstly, it is believed that attitude has influence on behaviour, (Kaballa and Crowley, 1985), secondly attitude influences success or achievement as said by Schibeei and Riley (1986). According to Abidin, Pour-Mohammadi and Alzwari, (2012, p.119) it is found that " it is good to know the language which can help us express our dreams and hopes" In the words of Fakeye, 2010 learner's attitude is acknowledged to be the most important factors that highly imparts language learning. Latchana and Dagnew, 2009 observed and said that attitude is accepted as a significant factor in understanding human behaviour and defines it as the mental state that comprises of beliefs and feelings.

The belief a learner has is directly reflected with success in language learning. There arise many questions when we look at the word attitude interconnected with language learning that is how to define attitude in connection with language learning? , how an attitude is formed? whether there could be change in the attitude of a learner or would it remain the same? etc. Kara, 2009 observed that "positive attitude leads to the exhibition of positive behaviour towards the course of study, with participants engaging themselves in courses and striving to learn more. Such students are observed to be much eager to solve problems and gather skills needed for every day need and participate themselves emotionally, the cognitive aspects of attitude involves the beliefs of the language learners about the knowledge that they receive and their perception in the course of learning a language (as cited in Abidin et al. 2012).

The cognitive aspect comprises the beliefs and understanding of the learners about the knowledge and the process of learning the language. The cognitive attitude could be classified into four by connecting the previous knowledge with the new one, creating new knowledge, checking new knowledge and implementing the new knowledge in many situations. Since attitude is regarded as one of the key factors for achievement Freg and Chen (2009) stated that "Learning process is an emotional process. It is affected by the emotional factors. A study was conducted on the EFL students focusing on the demographic variables like gender, background, year of study etc in terms of behavioural, cognitive and emotional aspects by Abidin et al. (2012). The participants showed a negative attitude towards learning English. Cabasang (2013) reported that attitude is the key variable in language learning and students accumulate information to gain knowledge and it they have positive outlook towards the target language; therefore it is the teacher who should look at the students feeling, beliefs and behaviour in order to address the intended knowledge of the target language.

Significance of the study: As there are many researchers conducting research on the affective filter variables, this study would interest such researchers focusing on the demographic variables such a background and gender of the ESL students.

Purpose of the study: The main purpose of this research is to study the students' attitude towards English learning at the tertiary level. To find, 1 . Whether there is a significant difference between the gender with regard to cognitive, behavioural and emotional aspects of attitude towards learning of English as second language? 2. Whether there is a significant difference with respect to the residential background?

Objectives of the study: The aim of the study was to know the students' attitude towards learning English as second language with particular reference to the tertiary level learners. The study also targeted to address the specific objectives:

1. To identify the behavioural, cognitive and emotional aspects of students attitude towards English language learning

2. To check whether gender or the residence affect their learning attitude.

\section{METHODOLOGY}

The study adopted random sampling technique and quantitative in nature. An adopted questionnaire was used to measure the variables. The study participants were well informed about the purpose of collecting data from them. They were asked to fill out the form since the data collection fell in the period of pandemic and students were attending online classes. It was not possible to do in person data collection. So, the research was carefully done after formulating the form, and the needed instructions the study participants were given with the link to access the google form and they were instructed to give their honest response which has served the paper with the existing result.

Participants: The study has employed the simple random sampling technique, where 63 (female $=52$ and male=11) students were selected as the study participants.

Instrument: The questionnaire adopted and used to collect data comprises of 30 items concerning language attitudes. The first 10 items refer to the behavioural, the second 10 items refer to the cognitive and the third 10 items indicates the emotional aspects of attitude. The statements were put in a five-point Likert scale from Level 1 strongly disagree to level 5 strongly agree. Reverse coding was done to 12 numbers of questions which are under behavioural aspect questions 1, 5, 6, 7, 9, 10, under cognitive questions 13, 16, 18, 19 and under emotional questions 1 and 2 were given reverse coding. The reverse coding was given to negative worded questions.

Analysis and Interpretation: The collected data have been analysed using SPSS software. The descriptive analysis shows the interpretation of the data collected. 
The independent t-test was done to identify the mean, standard deviation and significance between gender and the categorical variables were measured using one-way analysis of variance (ANOVA) to find the significance related to residential background since the behavioural and the cognitive variables had a significant difference Post-hoc test was applied to find the multiple comparison. The above table shows the result of the independent t-test which shows that there is no significant difference between the genders towards learning of English as a second language.

\begin{tabular}{|c|c|c|c|}
\hline \multirow[t]{2}{*}{ Variables } & Gender & & \multirow[t]{2}{*}{ Sig ( $P$ value) } \\
\hline & Male $(n=11)$ & Female $(n=52)$ & \\
\hline Behavioural & 37.1818 (3.9) & $38.1731(6.4)$ & 0.513 \\
\hline Cognitive & $38.2727(4.1)$ & 39.6731(5.9) & 0.464 \\
\hline Emotional & $34.6364(9.1)$ & $38.4423(7.1)$ & 0.132 \\
\hline
\end{tabular}

Table 2. One -way analysis of variance (ANOVA)

\begin{tabular}{|l|c|c|c|c|c|c|c|}
\hline \multirow{2}{*}{$\begin{array}{l}\text { Variable } \\
\text { Rural }\end{array}$} & \multicolumn{2}{c|}{ Urban } & \multicolumn{2}{c|}{ Suburban } & Sig \\
\hline Behavioural & 34.7000 & 4.94526 & 39.4222 & 5.41248 & 34.1250 & 8.02563 & ${ }^{*} .011$ \\
\hline Cognitive & 35.0000 & 4.00000 & 40.9778 & 5.06094 & 36.2500 & 7.16639 & ${ }^{*} .002$ \\
\hline Emotional & 34.5000 & 5.79751 & 38.8000 & 7.58767 & 36.1250 & 8.93528 & .219 \\
\hline
\end{tabular}

Table 3. Post-hoc multiple comparison test

\begin{tabular}{|l|c|c|c|}
\hline \multirow{2}{*}{ Variable } & \multicolumn{3}{|c|}{ Residence } \\
\cline { 2 - 4 } & $\begin{array}{c}\text { Rural Vs } \\
\text { Urban }\end{array}$ & $\begin{array}{c}\text { Rural Vs } \\
\text { Suburban }\end{array}$ & $\begin{array}{c}\text { Urban Vs } \\
\text { Suburban }\end{array}$ \\
\hline Behavioural & .021 & .833 & .019 \\
\hline Cognitive & .002 & .615 & .021 \\
\hline Emotional & .107 & .650 & .358 \\
\hline
\end{tabular}

Table 2 shows the one-way analysis of variance (ANOVA) test which is used to measure the significance related to the variables which are more than two and here we have three aspects to be measured they are behavioural, cognitive and the emotional aspects so this one-way analysis of variance (Anova) test has been used to find whether there exists significant difference between and within groups based on their residential background and it was found that the two attitudinal aspects Behavioural and Cognitive showed significant difference, whereas the emotional when compared to the behavioural and the cognitive did not show any statistically significant difference in the $\mathrm{P}$ value. This finding has led to the multiple comparison test called the post-hoc test to find the significance with respect to the behavioural and the cognitive attitudinal aspects towards learning of English as a second language.

Table 3 represents the post-hoc test which is done to find multiple comparison and it was done only for two attitudinal variables behavioural and cognitive with respect to the residential background, since there was a difference only in those two variables.

\section{RESULTS AND DISCUSSION}

Many factors play its role in finding the learners' attitude of learning English as second language. The present study is found to say that there is no significant difference in the gender towards learning of English as second language but the factor -residential background has an affectation in the learners' behavioural and cognitive aspects of attitude towards the learning of English as a second language.The same study can be conducted with other different variables such as age, social status, parental support etc. Since it is found that the affective filter variables have direct influence and affectation on the learning of English as second language every teacher is advised to carefully design the materials to fit to the entire class, having in mind the contribution of each factor that acts as a key to the learners' achievement.

\section{CONCLUSION}

To conclude it is understood that there are many affective filter variables that play a major role in the learners' attitude towards learning of English as a second language. This study focused on the affective variables that has key role in learning a language which paved way for the researchers to understand the factors that affect and influence the learners attitude in learning 
the English as a second language. Also this has made the researchers think how much of cautiousness should be there in the minds in receiving and providing the language to its best.

\section{ACKNOWLEDGEMENTS}

I owe my sincere gratitude to the almighty God for having given me the knowledge to contribute my ability to the ELT group. I extend my thanks to my research supervisor Dr.K. Anbazhagan, HOD, Dept of EFL, SRMIST, KTR for his constant support and guidance upon the completion of the work. I express my sincere thanks to Mrs. Gayathri Babu, Senior Lecturer in Statistics, Faculty of Allied Health Sciences, SRIHER (DU) for having done the statistical analysis for the research paper.

\section{REFERENCES}

Abidin, M. J. Z., Pour-Mohammadi, M., \&t Alzwari, H. (2012). EFL students attitudes towards learning English language: The case of Libyan secondary school students. Asian social science, 8(2), p119. (16) (PDF) Attitudes of Secondary School Students towards English as Foreign Language A case study at Lahore, Pakistan.pdf. Available from: https://www.researchgate. net/publication/311432213_Attitudes_of_Secondary_ School_Students_towards_English_as_Foreign Language_A_case_study_at_Lahore_Pakistanpdf [accessed Mar 29 2021].

Abidin, Pour-Mohammadi and Alzwari, (2012) .EFL Students' Attitudes towards Learning English Language: The Case of Libyan Secondary School Students www. ccsenet.org/ass, Asian Social Science, Vol. 8, No. 2; February 2012.

Fakeye, D. (2010) Students' Personal Variables as Correlates of Academic Achievement in English as a Second Language in Nigeria. Journal of Social Sciences, 22, 205-211.
Graddol, D. (1997). The future of English. The British Council. [Google Scholar]

https://doi.org/10.1080/09718923.2010.11892803

https://doi.org/10.14221/ajte.2009v34n3.5

J N. Cabansag (2013). The attitudinal propensity of students toward strategies in English language learning. Researchers World-Journal of Arts, Science \&t Commerce 4 (2), 10-18

Jack C. Richards and Richard Schmidt. (2002) Longman Dictionary of LANGUAGE TEACHING ANDAPPLIED LINGUISTICS, Fourth edition,p.297

Kaballa and Crowley, 1985 (source from Weinburgh, M. H. (1998)). Gender, Ethnicity, And Grade Level As Predictors Of. Middle School Students' Attitudes Toward Science. Www.Ed.Psu.Edu/Ci/Journals/1998aets/ S5_1_Weinburgh.Rtf (accessed time: 23.02.2004) Kara, A. (2009) The Effect of a 'Learning Theories' Unit on Students' Attitudes towards Learning. Australian Journal of Teacher Education, 34, 100-113.

KC Chen, WG Teng - (2009)Adopting user profiles and behavior patterns in a Web-TV recommendation system IEEE 13th International Symposium on Consumer .

Krashen, Stephen D. Principles and Practice in Second Language Acquisition. Prentice-Hall International, 1987.

Krashen, Stephen D. Second Language Acquisition and Second Language Learning. Prentice-Hall International, 1988.

Latchanna, G. \&t Dagnew, A. (June 2009). Attitude of teachers towards the use of active learning methods. E-journal of All India Association for Educational Research, 21(1), http://www.ejournal.aiaer. net/vol21109/12.\%20Latchana\%20\&\%20Dagnew.pdf Schibeei and Riley (1986) (as cited in Craker, D. E. (2006)). Attitudes toward science of students enrolled in introductory level science courses at UWLa Crosse, UW-L Journal of Undergraduate Research IX, 1-6. 